The Editor's recommendation of this issue's article to readers

\title{
RELATIONSHIP BETWEEN GENDER, TEACHING EXPERIENCE, SUBJECT TAUGHT, AND TEACHER'S ATTITUDE AND KNOWLEDGE TOWARD DENTAL TRAUMA IN CHILDREN
}

I am pleased to inform you that I have chosen this article by Anggono et al. ${ }^{1}$ as Editor's Choice for second issue of 2020.

Dental trauma is one of the most important problems among children in dental practice. Traumatic dental injuries are commonly seen at schools. Thus, teachers must be able to make emergency dental procedures. Within this rationale, assessing teacher's attitude and knowledge about dental trauma in children is critical.

This article revealed that the attitude toward dental trauma in children was positive whereas, knowledge about dental trauma was insufficient among the teachers.

Happy readings in the second issue of 2020 !

Burak Buldur

Editor

\section{REFERENCE:}

1. Anggono J, Budiardjo S.B, Fauziah E. Relationship Between Gender, Teaching Experience, Subject Taught, and Teacher's Attitude and Knowledge Toward Dental Trauma in Children. Cumhuriyet Dent J 2020;23:2;88-95. 